\title{
MOTIVASI, KEPUASAN KERJA DAN PRODUKTIVITAS PENYULUH PERTANIAN LAPANGAN: KASUS KABUPATEN SUKABUMI
}

\section{MOTIVATION, JOB SATISFACTION AND PRODUCTIVITY OF AGRICULTURE EXTENSION WORKER: CASE STUDY OF SUKABUMI DISTRICT}

\author{
Aida Vitayala S. Hubeis
}

\begin{abstract}
The objective of the study was to find out the motivation, job satisfaction and job productivity of Agriculture Extension Workers (AEW). Respondent of the study was 36 AEW at Sukabumi district, West Java. The results of study have shown that most extension agents are male, relatively old, married and having more than three children. Most of them have had diploma program, participated in several trainings, 20 years of working experience, and belonging to third rank employee. Internal factors of AEW (achievement, recognition, job and responsibility are the internal factors performed significance factors. The motivation of agriculture extension agents has influenced by intrinsic and extrinsic factors; Job satisfaction influenced by psychology, and social, while physical and financial factors have no influence; Job productivity influenced by internal (achievement, recognition, job, responsibility) and external factors (FEW status, interpersonal relation) education background and capacity building, skill, technology, working environment, and discipline. All internal factors, achievement-recognition-work-responsibility has siginificance influence to extension workers productive works.
\end{abstract}

Keywords: Extension, motivation, job satisfaction, job productivity.

\section{Pendahuluan}

Penyuluhan sebagai proses pembelajaran (pendidikan nonformal) yang ditujukan untuk petani dan keluarganya memiliki peran penting di dalam pencapaian tujuan pembangunan bidang pertanian. Penyuluh Pertanian Lapangan (PPL) sebagai komunikator pembangunan diharapkan dapat bermain multiperan, sebagai guru, pembimbing, penasehat, penyampai informasi dan mitrapetani. Karena itu, peningkatan kinerja PPL sangat penting di dalam mempertahankan kelangsungan program penyuluhan di tingkat lapangan. Hal ini erat kaitannya dengan motivasi dan kepuasan kerja yang dapat diperoleh oleh penyuluh.

Beberapa studi tentang penyuluh mengemukakan bahwa kinerja mereka relatif rendah. Menurut Widiyati (2000), rataan pekerja yang termotivasi akan menggunakan 80-90\% kemampuan dalam bekerja. Dan mereka yang tidak termotivasi hanya memakai 20-30\% kemampuannya dalam bekerja. Menurut teori dua faktor Herzberg dalam Stoner dan Freeman (1992), ada dua faktor yang mempengaruhi motivasi seseorang dalam bekerja: Pertama adalah faktor intrinsik meliputi unsur prestasi, pengakuan, pekerjaan, dan tanggung-jawab; 
Kedua adalah faktor ekstrinsik meliputi administrasi dan kebijakan, supervisi, gaji dan imbalan, hubungan interpersonal, kondisi kerja dan status.

Motivasi seseorang di dalam bekerja ada kaitannya dengan kepuasan kerja dan produktivitas kerja: Kepuasan kerja dipengaruhi oleh faktor psikologis, sosial, fisik, dan finansial. Sedangkan produktivitas kerja dipengaruhi oleh pendidikan dan pelatihan, keterampilan, teknologi, lingkungan kerja, disiplin kerja, dan balas jasa yang diterima. Tujuan penelitian adalah mengetahui profil karakteristik PP; mengetahui motivasi, kepuasan kerja, dan produktivitas kerja PPL; menganalisis hubungan motivasi dan kepuasan kerja dengan produktivitas kerja PPL.

\section{Metode Penelitian}

Penelitian dilakukan pada awal tahun 2005 terhadap 36 orang PPL, yang tersebar di 15 kecamatan di Kabupaten Sukabumi. Pemilihan PPL dilakukan secara acak dengan menggunakan Cluster Random Sampling. Pengumpulan data dilakukan dengan menggunakan kuesioner terstruktur dan Diskusi Kelompok Terarah (Diskorah).

Pengolahan data dilakukan dengan menggunakan analisis statistik deskriptif berupa tabel frekuensi, persentase, rataan dan total rataan skor, dan uji korelasi rank spearman dengan bantuan program SPSS.

\section{$\underline{\text { Hasil Dan Pembahasan }}$}

\section{$\underline{\text { Karakteristik PPL }}$}

Karakteristik PPL mencakup jenis kelamin, usia dan status perkawinan, pangkat dan golongan, dan pendidikan (formal dan non-formal).

\section{Jenis kelamin (gender)}

PPL terdiri dari 83\% laki-laki dan $17 \%$ perempuan. Sedikitnya jumlah PPL perempuan terkait dengan lokasi penelitian yang relatif jauh dari pusat kota dan terpencil sehingga jarang dari mereka yang ditempatkan atau bersedia bertugas di wilayah tersebut. Membanding dengan data tingkat nasional maka persentase ini juga tidak jauh berbeda dengan persentase perempuan PPL di tingkat nasional, yaitu sekitar $15 \%$.

\section{Usia dan status kawin}

Sebanyak 94\% PPL telah berusia senja, di atas 40 tahun; Usia PPL termuda adalah 32 tahun dan tertua 51 tahun. Semua PPL, lelaki dan perempuan telah menikah dengan $78 \%$ diantaranya memiliki anak 1-4 orang dan $22 \%$ memiliki anak dengan kisaran 5-8 orang.

\section{Pangkat dan golongan}

Sebanyak $81 \%$ PPL termasuk pada golongan III (Penata) dengan sebaran pada Penata Muda (50\%), Penata $(25 \%)$ dan Penata tingkat I (6\%). Sedang 19\% PPL lainnya termasuk pada golongan II (Pengatur). Sebanyak 78\% PPL sudah memiliki masa kerja lebih dari 20 tahun. Menurut waktu pertama kali PPL bekerja, yang terlama adalah mereka yang mulai bekerja pada tahun 1976 dan termuda pada tahun 1995.

\section{Pendidikan}

PPL berpendidikan D-3 berjumlah 80\%, 14\% SPMA, dan 6\% S-1. Banyaknya PPL berpendidikan D-3 merupakan implikasi kebijakan Departemen Pertanian (Deptan) tahun 90-an tentang perlunya pemberdayaan masyarakat petani secara lebih intensif. Atas dasar pemikiran ini maka Deptan menugasi PPL untuk mengikuti program D-3 bidang pertanian, peternakan, dan perikanan. Program ini sejalan dengan pembangunan pertanian yang semakin berkembang dan menuntut kemampuan prima PPL di dalam menyelenggarakan kegiatan penyuluhan di lapangan sebagai penyuluh pertanian polivalen yang dapat menangani beragam aspek pertanian dalam arti luas. Selain 
mengikuti program D-3 Deptan, ada juga PPL yang mengikuti program D-3 atau pendidikan S1 di Universitas Terbuka (UT).

Selain pendidikan formal, semua PPL pernah mengikuti pendidikan non formal (pelatihan dan kusus-kursus) yang terkait dengan pekerjaan mereka. Sebanyak 80\% PPL pernah mengikuti pelatihan lebih dari $10 \mathrm{kali}$, dan 17\% sebanyak 6-10 kali pelatihan. Sebanyak 3\% PPL yang baru mengikuti 2-5 pelatihan adalah mereka yang relatif berusia muda dengan masa kerja yang relatif belum lama dan atau bertugas di lokasi yang agak terpencil. Fakta ini didukung oleh angka 22\% PPL yang memiliki masa kerja kurang dari 10 tahun sehingga peluang mereka untuk mengikuti beragam pelatihan belum banyak. Selain pelatihan dan kursus, sebanyak $46 \%$ PPL pernah melakukan studi banding (widya wisata) atau kunjungan (karyawisata) ke daerah lain untuk melihat keberhasilan pelaksanaan kegiatan penyuluhan di daerah lain, sebagai bahan pembanding.

\section{$\underline{\text { Tingkat Motivasi PPL }}$}

Motivasi PPL mencakup motivasi instrinsik dan ekstrinsik.

\section{Motivasi intrinsik}

Faktor motivasi intrinsik PPL yang termasuk pada kategori skor baik adalah prestasi, pengakuan, dan tanggungjawab. Sedang skor pekerjaan termasuk pada kategori cukup (Lihat Tabel 1).

Tabel 1 Rataan skor variabel motivasi instrinsik PPL, Sukabumi 2006

\begin{tabular}{|l|c|c|}
\hline Variabel Motivasi Instrinsik & Rataan Skor & Kategori \\
\hline - Prestasi & 2.78 & Baik \\
\hline - Pengakuan & 2.52 & Baik \\
\hline - Pekerjaan & 2.09 & Cukup \\
\hline - Tanggungjawab & 2.59 & Baik \\
\hline Total Rataan Skor & 2.49 & Baik \\
\hline
\end{tabular}

Keterangan kategori: skor Buruk (1-1.65); skor Cukup (1.66-2.31); skor Baik (2.32-3.0)

Skor motivasi intrinsik (prestasi, pengakuan, dan tanggungjawab) termasuk pada kategori baik diindikasi oleh upaya keras PPL di lapangan untuk selalu berusaha mensolusi masalah pertanian yang diajukan petani binaan secara tepat dan cepat, pada saat pertemuan di kelompok atau saat kunjungan ke hamparan atau domisili. Kesempatan menyampaikan saran yang terkait dengan pembinaan kelompoktani dan masalah pertanian pada pertemuan rutin di BPP atau di Dinas merupakan alasan lain pendorong semangat PPL dalam bekerja. Penyelenggaraan penyuluhan pertanian yang terstruktur, secara tidak langsung juga menjadi sarana pemantau kinerja, pemenuhan tanggungjawab, dan kedisiplinan PPL dalam bekerja. Hal ini turut menumbuhkembangkan motivasi kerja penyuluh, termasuk keakraban jalinan relasi sosial yang baik dengan atasan dan sesama PPL.

Skor pekerjaan termasuk kategori cukup karena hampir sebagian besar penyuluh mengemukakan perasaan jenuh mereka melakukan pekerjaan serupa dari hari ke hari. Kejenuhan dalam bekerja, antara lain disebabkan oleh faktor imbalan jasa (terutama gaji) yang kecil, promosi kenaikan pangkat yang sulit, dan wilayah binaan yang sulit dijangkau. Apalagi, bantuan dana taktis/operasional tidak memadai, dan fasilitas kendaraan beroda dua (bagi mereka yang mendapat jatah) sudah banyak yang rusak. 


\section{Motivasi ekstrinsik}

Faktor motivasi ekstrinsik PPL yang termasuk pada kategori skor baik adalah administrasi dan kebijakan, supervisi, hubungan interpersonal, dan status. Sedangkan gaji dan imbalan, serta kondisi kerja termasuk pada kategori skor cukup (Lihat Tabel 2).

Tabel 2 Rataan skor variabel motivasi ekstrinsik PPL, Sukabumi2006

\begin{tabular}{|l|c|c|}
\hline Variabel Motivasi Ekstrinsik & Rataan Skor & Kategori \\
\hline - Administrasi dan kebijakan & 2.51 & Baik \\
\hline - Supervisi & 2.59 & Baik \\
\hline - Gaji dan imbalan & 1.95 & Cukup \\
\hline - Relasi/hubungan interpersonal & 2.52 & Baik \\
\hline - Kondisi kerja & 1.70 & Cukup \\
\hline - Status Rataan Skor & 2.92 & Baik \\
\hline & 2.36 & Baik \\
\hline
\end{tabular}

Keterangan kategori: skor Buruk (1-1.65); skor Cukup (1.66-2.31); skor Baik (2.32-3.0)

Skor motivasi ekstrinsik PPL (administrasi dan kebijakan, supervisi) termasuk pada kategori baik karena terkait dengan sistem penyelenggaraan penyuluhan yang eksis dan terstruktur di lapangan, yaitu Sistem TV (Training and Visit System). Sistem TV merefleksikan administrasi dan kebijakan terstruktur dan supervisi yang terjadual sehingga dapat menstimuli jalinan kekariban antara penyuluh dan kelompoktani dan dengan sesama penyuluh. Hal ini diindikasikan dengan skor hubungan interpersonal yang termasuk pada kategori baik.

Status PPL yang tergolong pada kategori baik terkait dengan ungkapan mereka bahwa status penyuluh sebagai pegawai negeri turut meningkatkan posisi mereka di dalam pandangan penduduk desa, dan petani pada khususnya.

Gaji dan imbalan yang tergolong pada kategori cukup terkait dengan kenyataan bahwa gaji yang diterima penyuluh tidak memungkinkan mereka memberdayakan diri dalam menyiapkan materi penyuluhan, sesuai dengan tuntutan lapangan. Akibatnya, materi penyuluhan yang disampaikan ke kelompoktani binaan lebih banyak bergantung pada ketersediaan bahan penyuluhan dari pusat atau daerah.
Bahkan kondisi kerja di lapangan juga tidak selalu memungkinkan mereka untuk menggunakan bahan tertulis sehingga perlu adanya kreativitas dalam membuat bahan pembelajaran dengan memakai media asli.

\section{Tingkat Kepuasan Kerja PPL}

Faktor yang mempengaruhi kepuasan kerja PPL sebagai penyuluh dan tergolong pada kategori baik adalah faktor psikologis, dan sosial. Sedangkan faktor fisik tergolong pada kategori cukup dan faktor finansial tergolong pada kategori buruk (Lihat Tabel 3).

Secara psikologis, hampir semua PPL menyatakan bahwa mereka merasa bangga menjadi penyuluh yang acap diapresiasikan oleh banyak pihak sebagai ujung tombak pembangunan pertanian. Dan mereka juga memiliki relasi sosial yang baik dengan kelompok tani binaan, termasuk dengan aparat desa dan tokoh masyarakat setempat, sehingga ada perasaan nyaman dan aman secara hubungan sosial.

Faktor usia dinyatakan penyuluh sebagai kendala fisik utama bagi mereka untuk mengunjungi kelompoktani binaan yang berlokasi jauh dan harus ditempuh 
Tabel 3 Rataan skor kepuasan kerja PPL, Sukabumi, 2006

\begin{tabular}{|l|c|c|}
\hline Faktor Kepuasan Kerja & Rataan Skor & Kategori \\
\hline - Psikologis & 2.54 & Baik \\
\hline - Sosial & 2.88 & Baik \\
\hline - Fisik & 2.22 & Cukup \\
\hline - Finansial & 1.58 & Buruk \\
\hline Total Rataan Skor & 2.31 & Cukup \\
\hline
\end{tabular}

Keterangan kategori: skor Buruk (1-1.65); skor Cukup (1.66-2.31); skor Baik (2.32-3.0)

dengan berjalan kaki atau dengan sarana angkutan seadanya.

Rata-rata penyuluh tergolong berusia senja, dan karena itu unsur fisik penyuluh termasuk kategori skor cukup di dalam memotivasi PPL bekerja.

Secara psikologis, hampir semua PPL menyatakan bahwa mereka merasa bangga menjadi penyuluh yang acap diapresiasikan oleh banyak pihak sebagai ujung tombak pembangunan pertanian. Dan mereka juga memiliki relasi sosial yang baik dengan kelompok tani binaan, termasuk dengan aparat desa dan tokoh masyarakat setempat, sehingga ada perasaan nyaman dan aman secara hubungan sosial.

Faktor usia dinyatakan penyuluh sebagai kendala fisik utama bagi mereka untuk mengunjungi kelompoktani binaan yang berlokasi jauh dan harus ditempuh dengan berjalan kaki atau dengan sarana angkutan seadanya. Rata-rata penyuluh tergolong berusia senja, dan karena itu unsur fisik penyuluh termasuk kategori skor cukup di dalam memotivasi PPL bekerja.

Faktor finansial tergolong pada kategori skor buruk karena hampir semua penyuluh menyatakan bahwa gaji dan tunjangan fungsional yang diterima tidak mencukupi, apalagi bagi mereka dengan keluarga besar. Kondisi ini memotivasi sebagian penyuluh untuk melakukan pekerjaan sambilan. Hal ini terkadang berbenturan dengan pekerjaan mereka sebagai penyuluh, agent of change di sektor pertanian.

\section{Tingkat Produktivitas Kerja PPL}

Faktor yang mempengaruhi produktivitas kerja PPL sebagai penyuluh dan mendapat skor baik adalah pendidikan dan pelatihan, keterampilan, teknologi, lingkungan kerja, dan disiplin kerja. Hanya faktor balas jasa yang tergolong pada kategori skor buruk. (Lihat Tabel 4).

Tabel 4 Rataan skor faktor produktivitas PPL, Sukabumi, 2006

\begin{tabular}{|l|c|c|}
\hline \multicolumn{1}{|c|}{ Faktor Produktivitas Kerja } & Raataan Skor & Kategori \\
\hline - Pendidikan dan pelatihan & 2.70 & Baik \\
\hline • Keterampilan & 2.57 & Baik \\
\hline - Teknologi & 2.50 & Baik \\
\hline - Lingkungan kerja & 2.60 & Baik \\
\hline - Disiplin kerja & 2.46 & Baik \\
\hline - Balas jasa $\quad 1.11$ & Buruk \\
\hline & 2.32 & Baik \\
\hline
\end{tabular}

Keterangan kategori: skor Buruk (1-1.65); skor Cukup (1.66-2.31); skor Baik (2.32-3.0) 
Tabel 4 menunjukkan bahwa secara keseluruhan rataan skor produktivitas PPL tergolong pada kategori baik. Hal ini dikarenakan sebagian besar PPL berpendidikan D-3 dan telah mengikuti lebih dari 10 jenis pelatihan yang terkait dengan pekerjaan mereka sebagai penyuluh. Selain itu, masa kerja puluhan tahun dari penyuluh turut mendukung kemampuan mereka di dalam menguasai materi penyuluhan dan mengoperasikan ragam media teknologi penyelenggaraan penyuluhan, seperti OHP, peta singkap dan leaflet. Akan tetapi untuk penggunaan infocus maka hampir semua penyuluh menyatakan masih perlu menguasai penggunaannya, agar dapat meningkatkan kinerja dan penampilan, saat menyampaikan hasil pembinaan lapangan di kantor.

Lingkungan kerja mendapat skor baik karena didukung oleh pengalaman tahunan menyuluh yang memungkinkan tiap penyuluh mudah beradaptasi dan bergaul baik dengan petani binaan. Selain itu, penguasaan bahasa lokal dan adat-istiadat setempat memungkinkan penyuluh menumbuhkan lingkungan kerja berkesetaraan, antara penyuluh dan petani binaan. Dengan kata lain, lingkungan kerja PPL dengan skor baik adalah sangat kondusif di dalam menstimuli produktivitas kerja mereka, walaupun harus menempuh jarak jauh dan membina kelompoktani dalam jumlah yang banyak.

Disiplin kerja termasuk dalam kategori baik. Walaupun wilayah kerja yang luas serta fasilitas transportasi yang belum memadai, PPL tetap melakukan kunjungan kerja tiap minggu ke semua kelompoktani binaan dengan frekuensi yang tinggi (5-8 kali per minggu), sesuai dengan prosedur dan mekanisme kerja.

Faktor balas jasa tergolong pada kategori buruk karena sebagian besar PPL masih dikendalai oleh kesulitan memperoleh penghargaan, dan bahkan untuk kenaikan golongan juga demikian. Misalnya, tidak semua penyuluh berkesempatan untuk turutserta dalam suatu penelitian yang memungkinkan mereka menambah kredit poin kenaikan pangkat. Padahal nilai kredit poin untuk penelitian dan menulis jurnal besar sekali dibanding dengan pekerjaan rutin mereka sebagai penyuluh yang bernilai 00.7 poin dalam perhitungan kenaikan pangkat dan golongan. Karena itulah faktor balas jasa terhadap produktivitas PPL mendapat skor buruk.

\section{Hubungan Motivasi dengan Tingkat Produktivitas Kerja PPL}

Motivasi penyuluh dalam konteks produktivitas kerja dipengaruhi oleh faktor internal dan faktor eksternal: Hasil uji korelasi rank spearman menunjukkan bahwa semua faktor internal (prestasi, pengakuan, pekerjaan, tanggungjawab) berkorelasi positif dengan produktivitas kerja penyuluh; Faktor eksternal yang berkorelasi positif yaitu status penyuluh sebagai change agents of agriculture development dan hubungan interpersonal antara penyuluh dan petani, dengan sesama penyuluh, dan kepada atasan. Sedangkan faktor administrasi dan kebijakan, supervisi, gaji dan imbalan, dan kondisi kerja) berkorelasi negatif (Lihat Tabel 5).

Tabel 5 menunjukkan bahwa secara bersama-sama, motivasi internal dan eksternal PPL yang rendah menyebabkan produktivitas kerja mereka juga menjadi rendah.

\section{Motivasi internal}

Motivasi penyuluh untuk berprestasi berkorelasi positif dengan produktivitas kerja PPL yang berarti semakin tinggi upaya penyuluh mensolusikan masalah yang dihadapi kelompoktani binaannya maka semakin tinggi juga produktivitas kerja penyuluh yang bersangkutan. Sebagai contoh, ketika terjadi kelangkaan pupuk maka penyuluh tidak merasa segan mencari alternatif sumber pupuk bagi petani dengan memanfaatkan relasi mereka dengan penyalur pupuk dari lokasi lain. 
Tabel 5 Korelasi Faktor Motivasi dengan Produktivitas kerja PPL, Sukabumi 2006

\begin{tabular}{|l|c|c|}
\hline \multirow{2}{*}{ Faktor yang Mempengaruhi Motivasi } & \multicolumn{2}{|c|}{ Produktivitas Kerja } \\
\cline { 2 - 3 } & Nilai Korelasi Rs & P value \\
\hline Faktor Internal & 0.044 & 0.801 \\
\hline • Prestasi & 0.146 & 0.397 \\
\hline • Pengakuan & 0.171 & 0.318 \\
\hline • Pekerjaan & 0.097 & 0.573 \\
\hline • Tanggungjawab & \multicolumn{2}{|c|}{} \\
\hline Faktor Eksternal & -0.183 & 0.284 \\
\hline • Administrasi dan kebijakan & -0.167 & 0.330 \\
\hline • Supervisi & -0.117 & 0.496 \\
\hline - Gaji \& imbalan & 0.167 & 0.331 \\
\hline • Hubungan interpersonal & -0.150 & 0.382 \\
\hline - Kondisi kerja & 0.036 & 0.833 \\
\hline - Status Motivasi & -0.212 & 0.214 \\
\hline \multicolumn{2}{|l|}{}
\end{tabular}

Hubungan antara pengakuan dan produktivitas kerja PPL bernilai positif, yang berarti semakin tinggi pengakuan dari kedinasan terhadap kinerja penyuluh maka produktivitas kerja penyuluh pun akan semakin meningkat. Hal ini terrefleksi dengan adanya perhatian dan apresiasi atasan/dinas atas keberadaan penyuluh sebagai agent of change di tingkat akar bawah pembangunan pertanian.

Berdasarkan hasil uji korelasi Rank Spearman, hubungan antara pekerjaan dan produktivitas kerja PPL bernilai positif. Artinya semakin tinggi sikap PPL terhadap pekerjaannya maka produktivitas kerjanya pun akan semakin tinggi, dan begitu pula sebaliknya. Selain itu, sebagian besar penyuluh sudah berkerja lebih dari 20 tahun sehingga tidak ingin mencari pekerjaan lain, dan merasa telah berguna bagi pembangunan pertanian. Karena itu, tanggungjawab dan disiplin kerja penyuluh juga tergolong pada kategori skor baik (Lihat Tabel 1 dan 4).

\section{Motivasi eksternal}

Motivasi eksternal penyuluh yang berkorelasi positif dengan produktivitas kerja adalah status penyuluh dan hubungan interpersonal antara penyuluh dan kelompoktani, dengan sesama penyuluh dan dengan atasan. Sedangkan unsur motivasi eksternal lainnya berkorelasi negatif.

Prosedur administrasi dan kebijakan mekanisme penyuluhan berkorelasi negatif dengan produktivitas kerja penyuluh. Menurut pengakuan penyuluh, secara formalitas unsur ini sebenarnya mudah dan sederhana, tapi secara teknis cukup sulit untuk dilaksanakan karena wilayah kerja binaan per PPL relatif luas dan jarak antara UPP dan KPP pada umumnya sangat jauh. Akibatnya, tidak jarang jadual kunjungan penyuluhan tidak selalu tepat waktu; Unsur supervisi berkorelasi negatif dengan produktivitas kerja penyuluh. Hal ini erat kaitannya dengan asumsi bahwa pendidikan dan keterampilan penyuluh sudah tergolong tinggi, sehingga tidak diperlukan lagi pengawasan ketat bagi mereka dalam bekerja. Padahal, dengan adanya ubahan status penyuluh sebagai pegawai pemda dan bukan langsung pegawai kedinasan justru pengawasan yang melekat masih tetap diperlukan.

Gaji dan imbalan dan kondisi kerja berkorelasi negatif dengan produktivitas kerja PPL. Hal ini dapat dianggap wajar mengingat gaji dan tunjangan fungsional mereka yang 
belum memadai dibanding tugas mereka di lapangan yang harus berkeliling ke kelompoktani binaan yang banyak dan berjarak jauh.

Kondisi kerja PPL pun belum tergolong baik, mengingat bangunan fisik kantor yang sebagian besar sudah rusak dan kurang terawat serta ditambah dengan kondisi alat transportasi yang belum terpenuhi secara optimal. Tetapi hasil diskusi kelompok dan pengamatan lapangan menunjukkan bahwa sebagian besar penyuluh tidak terlalu mempersoalkan hal tersebut. Motivasi internal, yaitu komitmen tinggi dan tanggungjawab terhadap pekerjaan, merupakan faktor pendorong penyuluh untuk tetap komit dengan pekerjaannya.

Hubungan interpersonal dan status penyuluh berkorelasi positif dengan produktivitas kerja penyuluh. Artinya hubungan interpersonal berperan penting dalam penyelenggaraan penyuluhan.
Menurut penyuluh, hubungan mereka dengan atasan maupun dengan sesama penyuluh telah terjalin dengan erat dan penuh kekeluargaan, saling-bantu dalam melakukan kegiatan penyuluhan. Status sebagai aparat Pemda berperan penting di dalam memotivasi penyuluh untuk menjaga kewibawaan pegawai negeri. Selain itu, kepercayaan kelompoktani terhadap keberadaan penyuluh yang sudah dianggap sebagai aset narasumber pertanian merupakan tuntutan bagi penyuluh untuk bekerja lebih baik.

\section{Hubungan Kepuasan Kerja dengan Tingkat Produktivitas Kerja PPL}

Perasaan puas atas prestasi dan imbalan yang diterima akan memacu semangat kerja penyuluh untuk bekerja lebih baik lagi Hasil analisis menunjukkan bahwa tiga dari empat unsur kepuasan kerja yang diuji menunjukkan adanya korelasi positif (Lihat Tabel 6).

Tabel 6 Korelasi faktor kepuasan kerja dengan produktivitas kerja PPL, Sukabumi 2006

\begin{tabular}{|l|c|c|}
\hline \multirow{2}{*}{ Faktor Kepuasan Kerja } & \multicolumn{2}{c|}{ Produktivitas Kerja } \\
\cline { 2 - 3 } & Nilai Korelasi Rs & Pvalue \\
\hline - Psikologis & 0,101 & 0,558 \\
\hline - Sosial & 0,067 & 0,687 \\
\hline - Fisik & 0,207 & 0,227 \\
\hline - Finansial & $-0,097$ & 0,573 \\
\hline - Kepuasan Kerja & $\mathbf{0 , 0 1 8}$ & $\mathbf{0 , 9 1 8}$ \\
\hline
\end{tabular}

Faktor psikologis merupakan aspek kejiwaan penyuluh, seperti minat, sikap terhadap kerja, ketentraman bekerja, dan bakat; Minat penyuluh yang kuat berawal dari keinginan mereka untuk mensolusi masalah petani dalam upaya peningkatan kesejahteraan petani dan keluarganya. Sedang keamanan lingkungan kerja yang aman, tertib dan terkendali memberi ketenteraman bagi penyuluh pada saat bertugas, siang hari atau malam hari. Menurut penyuluh, umumnya mereka tidak mengenal waktu kerja, siap membantu petani kapan saja diperlukan.
Dengan kata lain, semakin tinggi minat penyuluh dalam bertugas dan dengan lingkungan kerja yang aman dan tentram maka produktivitas kerja mereka juga semakin tinggi; Bakat dan kemampuan penyuluh yang mencakup latar belakang pendidikan dan pelatihan merupakan indikasi kompetensi penyuluh (Lihat Tabel 1). Dengan demikian, rataan penyuluh umumnya cenderung memiliki kepercayaan diri yang tinggi di dalam menghadapi tiap masalah yang diajukan dan ditanyakan oleh kelompoktani binaan. 
Keseluruhan penyuluh mengaku puas dengan relasi sosial yang telah mereka bina dengan kelompoktani binaan: Relasi yang berkesetaraan membuat mereka leluasa berdiskusi dengan atasan, sebagai kolega dan mitra kerja; Demikian pula hubungan dengan sesama rekan penyuluh.Tidak jarang mereka saling-bantu dalam mensolusi masalah pertanian di wilayah binaan masing-masing; Sedangkan kedekatan penyuluh dengan petani binaan dan pemuka masyarakat sangat membantu di dalam melancarkan penyelenggaraan kegiatan penyuluhan. Misal, program Sekolah Lapangan Pemberantasan Hama Terpadu (SLPHT) dan widiawisata atau karyawisata dapat berlangsung baik dengan adanya dukungan dari Kades, selain kerjasama dengan pemuka tani.

Mengacu data pada Tabel 6, faktor finansial memiliki hubungan negatif dengan produktivitas kerja PPL, karena hampir semua penyuluh memang merasa tidak puas terhadap kesesuaian gaji, penghargaan dan tunjangan fungsional yang mereka terima selama ini. Namun, dalam realita, ternyata hal itu tidak berpengaruh terhadap produktivitas kerja penyuluh dengan adanya komitmen kuat mereka untuk melakukan tugas secara profesional, dalam kondisi apa pun.

Data pada Tabel 6 menunjukkan bahwa faktor fisik bernilai positif, yang berarti semakin baik kondisi fisik PPL maka produktivitas kerjanya pun akan semakin tinggi. Berdasarkan hasil Diskorah, wilayah kerja sebagian besar penyuluh diungkapkan sebagai terlalu luas dan sulit dijangkau serta tidak didukung dengan ketersediaan sarana transportasi yang memadai. Ternyata, hal itu juga tidak mengurangi semangat kerja penyuluh karena mereka telah terbiasa dengan kondisi seperti itu. Namun usia dari sebagian besar penyuluh yang relatif sudah tergolong usia senja acap mengendalai mereka dalam bertugas. Dalam hal ini, kemampuan memilah jadual dan lokasi kunjungan dan lokasi merupakan tuntutan bagi penyuluh untuk mampu membagi waktu mereka dengan baik.

\section{Simpulan}

Jumlah PPL laki-laki lebih banyak daripada PPL perempuan; Semua PPL telah menikah, relatif berusia "senja", dan memiliki tanggungan keluarga lebih dari 3 orang; Ratarata berpendidikan D-3 dan pernah mengikuti pelatihan atau kursus terkait dengan tugas mereka sebagai penyuluh; Sebagian besar termasuk golongan III dengan rataan masa kerja 20 tahunan.

Hasil uji korelasi rank spearman menunjukkan bahwa semua faktor internal (prestasi, pengakuan, pekerjaan, dan tanggungjawab) berkorelasi positif dengan produktivitas kerja PPL; Faktor eksternal yang berkorelasi positif dengan produktivitas kerja penyuluh yaitu status penyuluh dan hubungan interpersonal. Sedang faktor administrasi dan kebijakan, supervisi, gaji dan imbalan, dan kondisi kerja berkorelasi negatif dengan produktivitas kerja PPL.

Hasil uji korelasi rank spearman menunjukkan bahwa tiga dari empat unsur kepuasan kerja (psikologis, sosial, dan fisik) berkorelasi positif dengan produktivitas kerja PPL. Dan hanya unsur finansial yang berkorelasi negatif.

\section{$\underline{\text { Rujukan }}$}

As'ad, M. 1987. Psikologi Industri, edisi ke Tiga. Yogyakarta: Liberty.

Gibson, et.al., 1997. Organisasi dan Manajemen (Perilaku, Struktur, dan proses). Edisi keempat. Jakarta: Erlangga.

Hubeis, Aida V., 2001. Profil Penyuluh Pertanian di Jawa Barat.

Puspadi, Ketut. 2002. "Rekonstruksi Sistem Penyuluhan Pertanian". Disertasi. Bogor: Program Pascasarjana Institut Pertanian Bogor.

Van den Ban, A. W., dan H.S. Hawkins. 1999. Penyuluhan Pertanian. Yogyakarta: Kanisius. 
Widiyati, Kurnia. 2000. "Analisis produktivitas tenaga kerja dan faktor yang mempengaruhinya di PT. Saung Mirwan, Cisarua, Bogor." Skripsi. Fakultas Teknologi Pertanian IPB. Bogor.

Winardi, J. 2001. Motivasi dan Pemotivasian dalam Manajemen. Jakarta: Rajawali Pers.

Wisnuwardhana, Agung. 2001. Hubungan Faktor-faktor motivasi dengan kualitas kerja Penyuluh Kehutanan Lapangan. Skripsi. Bogor: Fakultas Kehutanan, Institut Pertanian Bogor. 